\title{
Erratum to: 23 November 1980 Irpinia-Basilicata earthquake (Southern Italy): towards a full knowledge of the seismic effects
}

\author{
F. T. Gizzi - M. R. Potenza - C. Zotta
}

Published online: 3 January 2013

C Springer Science+Business Media Dordrecht 2012

\section{Erratum to: Bull Earthquake Eng (2012) 10:1109-1131 DOI 10.1007/s10518-012-9353-Z}

We found mistakes in Figs. 4 and 5. In detail, the intensity value "VI MCS" that appeared in the inset of Fig. 4 and the legend/caption of Fig. 5 should be replaced by "VI/VI-VII MCS".

The online version of the original article can be found under doi:10.1007/s10518-012-9353-z.

F. T. Gizzi $(\varangle) \cdot$ M. R. Potenza · C. Zotta

Institute for Archaeological and Monumental Heritage, National Research Council,

C.da S.Loja, 85050 Tito Scalo, PZ, Italy

e-mail: f.gizzi@ibam.cnr.it 